\title{
Regional Potential Optimization Model in Increasing Local Revenue of Maybrat Regency, West Papua Province
}

\author{
Bernard Sagrim ${ }^{1}$, Khasan Effendy ${ }^{2}$ Ngadisah $^{3}$, Sampara Lukman ${ }^{4}$ \\ 1,2,3,4 Institut Pemerintahan Dalam Negeri (IPDN), Indonesia \\ Email: bernardsagrim05@gmail.com
}

\begin{abstract}
This study aims to find an optimal model for the development of regional potential owned by Maybrat Regency, West Papua Province, to increase local revenue for its people's welfare. Qualitative methods are used in this research using a post-positivism paradigm design, which seeks to reveal a social reality that ontologically can never be fully understood due to the limitations of human nature. The results show that the regional potential optimization model in Maybrat Regency is different from other regions because Maybrat Regency has special autonomy, which provides the broadest possible opportunity for local governments to manage all the potential to increase local revenue. The increase in the original region requires the support of political stability, availability, and quality of human resources, the quality of supporting facilities to create a good investment climate. West Papua Maybrat Regency Government.
\end{abstract}

Keywords: Regional Potential, Regional Original Income, Special Autonomy.

\section{A. INTRODUCTION}

Political decentralization carried out in Indonesia is a political reform effort at the local level to realize regional autonomy based on democratization, empowerment, and strengthening of local wisdom, so that the acceleration of community welfare through improved services, empowerment, and community participation, increasing regional competitiveness by taking into account, the utilization of natural resources and local economic resources based on equity, justice, privileges, and specialties of a region in the system of the Unitary State of the Republic of Indonesia (Simanjuntak, 2015; Hadiz, 2004; Nordholt, 2005).

In line with the conditions above, the policy regarding Papua's designation as a unique autonomous region can be seen as one form of actualization of this paradigm shift (Tryatmoko, 2016). This policy is based on the awareness that the political decision to unify West Irian (now Papua) to become part of the Unitary State of the Republic of Indonesia (NKRI), in essence, contains lofty aspirations for the progress of the people in Papua. However, the reality shows that the various policies implemented in the context of governance and development in Papua and West Papua Provinces have not fully enabled welfare and a sense of justice for the people (Musa'ad, 2016). On the contrary, it is felt that there are discriminatory actions, neglect of human rights (HAM), and indigenous Papuans' fundamental rights. This condition has resulted in disappointment that has led to the weakening of the people's trust, primarily indigenous Papuans in the government, expressed in 
various forms, including the desire to separate from the Republic of Indonesia (King, 2004; McGibbon, 2003).

The realization of the decentralized system is outlined by the application of regional autonomy and autonomous regions. Juridically, the concept of autonomous regions and regional autonomy contains elements of the authority to regulate and administer. The authority to regulate and administer is the substance of regional autonomy (Clark, 1984). The spatial and community aspects that have and are involved in regional autonomy have been apparent since the formation of the autonomous region. However, what needs further clarity is the content of the authority covered by regional autonomy. Therefore, in addition to the formation of autonomous regions, what is covered in the decentralization concept is the handover of the authority for government affairs. With the government's handover of government affairs to the autonomous areas, government affairs are distributed (Boetti et al., 2012; Isufaj, 2014).

Law no 21 of 2001 regulates the individual autonomy of Papua. The principle of special autonomy for Papua (later also followed by West Papua as a province resulting from the division) referred to in this law is that the region is given the authority to manage and regulate all government affairs outside those of the government, to improve public welfare, public services, and regional competitiveness. As a realization of the regional government law, regional governments respond by making various regulations or regulations to support autonomy in their regions. Rules made by local governments are one of the stick holders for the implementation of regional autonomy. In practice, it does not mean that regulation is made without the support of good performance. To realize the implementation of regional laws and regulations that have been made, local governments, in particular, need an implementation tool both in the form of an organization and human resources (Haris, 2005). The authority that the regional government has in terms of autonomy allows the creation of various instruments in the form of local apparatus that function as supporters of governance implementation in their regions (Muin, 2014).

The implementation of special autonomy is a golden opportunity for the Papuan people to organize themselves (Joku, 2007). This is because local communities can set common goals with a bottom-up process to strengthen democracy. Likewise for the provincial government and of course also for districts/cities in West Papua, apart from being a strategic entry point in maintaining regional government, special autonomy is also expected to solve problems in Papua Province, especially issues of community welfare, not only aimed at reducing conflict ( Mollet, 2011; Webb-Gannon, 2014)

Maybe at Regency is a regency located in West Papua Province. The condition of the Maybrat Regency area provides an overview of the regional states and the development achievements of the Maybrat Regency in general. Maybe at Regency became an administrative district based on Law Number 13 of 2009 due to the expansion. Geographically, Maybrat Regency is located at 131o00'-133o00 'East 
Longitude and 01o00'-02o30' LS, with an altitude between 0-2000m above sea level. Maybe at Regency is geographically an inland area, relatively low hilly and bordered by high mountains on the eastern side of the bird's head region of West Papua Province, which has unique bioregions throughout the province. The geographical position of Maybrat Regency has boundaries, among others: in the north, it is bordered by Fef District, Tambrauw Regency, Senopi District, and Kebar District, Manokwari Regency; The East is bordered by the North Moskona District; and South Moskona District, Bintuni Bay Regency.

Maybe at Regency is an area with various natural and human potentials that can improve its people's welfare. One of the possibilities possessed by Maybrat Regency is its abundant natural resources. This condition can be seen from the strategic position of Maybrat Regency, especially the mountains and slopes, which include Ayamaru, North Ayamaru, Mare, Aifat, East Aifat, and parts of Aitinyo, and the lowlands covering aspects of Aitinyo District. This strategic position affects the potential of natural resources, especially energy such as oil, gas, geothermal, and coal, and mineral resources such as limestone, phosphate rock, dolomite limestone, marble, and kwarsite, clay, and quartz sand (Cipta Karya, 2005).

Apart from energy and mineral resources, Maybrat Regency can also develop food crops, industry, and plantations, which can be seen from the soil, information, fertility, and water availability. The types of food crops that can become commodities for Maybrat Regency include lading rice, lowland rice, corn, soybeans, and green beans. Meanwhile, in the plantation context, the potential in Maybrat Regency can be through plants such as rubber, oil palm, coconut, cocoa, coffee, rambutan, mango, and banana. Next is the potential for forest plants such as Merbau and sago and non-timber possibilities such as forest honey, leaves, fruit, starch, medicinal ingredients, natural landscapes, flora, and fauna that can become potential forest tourism attractions in Maybrat Regency. Besides, other possible resources developed in Maybrat Regency are fisheries and fish cultivation, especially in the coastal area, which has swamp forests and mangroves as shrimp nurseries (Cipta Karya, 2005).

Forestry potential can also be seen through the use of the ferns Diplazium esculentum Swartz, which contributed to the household income of farmers, especially in North Aifat District, amounting to 42.53 or \pm 1.55 with the enormous value of around IDR 1,250.00-1,440,000 / month. These ferns can be used as local handicrafts such as Koba-Koba, which functions to protect themselves during rain and noken used during harvest. In addition to these various natural resource potentials, Maybrat Regency also has tourism potential such as the Frame Fund, Upper Lake, and Puncak Petik Bintang, which are expected to increase original income.

The above potentials can be an opportunity for alternative solutions in increasing Regional Original Income, from now on referred to as PAD as the regional economy's driving force. This potential is divided into six main sectors: mining and minerals, agriculture, plantation, forestry, marine and fisheries, and 
tourism. This potential needs to be managed optimally to create benefits that lead to an increase in PAD. The existence of this potential will affect not only economic aspects but also the development and regional independence. When the Deconcentration Fund supports the PAD, the Special Allocation Fund (DAK), the Special Autonomy Fund, has the opportunity to increase local expenditure, which leads to optimal accommodation of various interests and needs of the community (Wandira, 2013; Nuarisa, 2013; Mualim, 2010).

Based on the description above, the Maybrat Regency Government needs to take advantage of all its potential to increase its regional income. For this reason, an appropriate and ideal model is required to optimize the existing potential and then convert it into income, which can improve the welfare of the people of Maybrat Regency itself.

\section{B. METHOD}

The research design used is qualitative. Numbers cannot measure qualitative research deals with the ideas, perceptions, opinions, beliefs of the person being studied and as a whole. The author's selection of qualitative research methods is assumed to be appropriate to understand the problems contained in the research object, including those related to the research objectives to be achieved. This is because qualitative research is multi-method in focus, involving an interpretive, naturalistic approach to the subject matter. This means that qualitative researchers study something in a natural state, understand, or interpret existing phenomena. (Thomas, 2003).

The author positions this research preference using the post-positivism paradigm, which seeks to reveal a social reality that ontologically can never be fully understood due to human nature's limitations. Therefore, researchers use various data sources (primary and secondary) to understand social reality more. Different key informants are the source of preliminary data. Furthermore, the research methodology will be further explained through the following elaboration: research design, conceptual research framework, required data, informants/respondents and how to determine them, data collection techniques and instruments, data analysis techniques, location, and research schedule (Kuhn, 1970; Guba, 1990; Denzin, 2010).

\section{RESULT AND DISCUSSION}

As regulated in Law no. 33 of 2004, regional finance in Indonesia gives authority to regions in regulating and managing their finances that come from various sources, namely Regional Original Income (PAD), balancing funds, and other income. Regional Original Revenue itself is a revenue source for the Regional Government in supporting the implementation of the regional autonomy implementation process. PAD itself consists of four main elements, namely taxes, levies, proceeds from the management of separated local assets, and other legal PAD. Based on this, and the following models can be formed: 


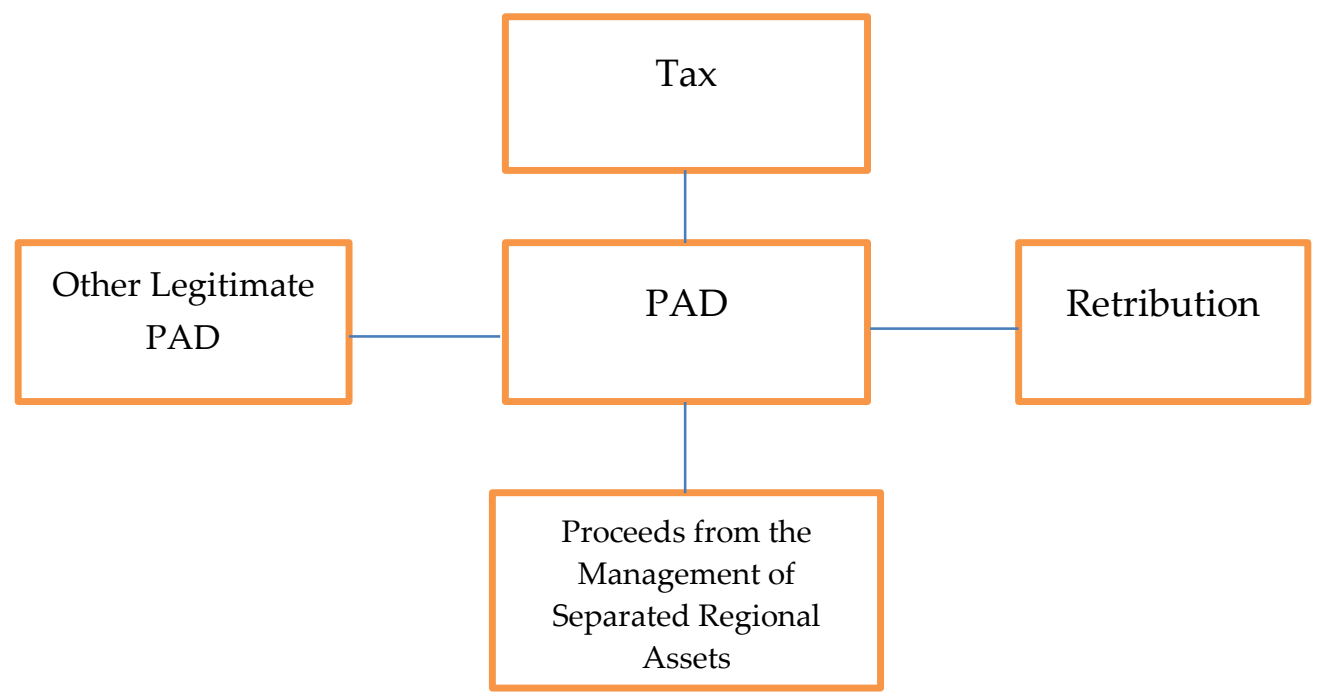

Figure 1. Model Law No. 33 of 2004

This model shows that the increase in PAD can be done by optimizing these four main elements. In other contexts, legitimate PAD consists of; a) proceeds from the sale of regional assets that are not separated; b) current account service; $c$ ) interest income; d) gain on the difference between the rupiah exchange rate against foreign currencies, and; e) commission, discount, or other forms as a result of sales and/or procurement of goods and / or services by the region. However, the optimization of PAD has restrictions, especially in the stipulation of Regional Regulations (Perda) on revenue, which causes a high-cost economy and hinders population mobility, traffic of goods and services between regions, and import/export activities.

The phenomenon is quite different for regions in Papua and West Papua Provinces, such as the Maybrat Regency, which has special autonomy as the basis for implementing regional government. Referring to Law Number 21 of 2001 concerning Special Autonomy for Papua Province divides the sources of revenue for the Province and Regency / City into five things, namely; a) Province, Regency / City original revenue; b) balance funds; c) Provincial revenues in the framework of Special Autonomy; d) regional loans; e) other valid receipts. Meanwhile, in the context of the province's income, the Regency / City consists of; a) local taxes; b) regional charges; c) proceeds from regional-owned enterprises and results of other separated regional assets management, and; d) other legal regional income, which can be formed in the following model: 


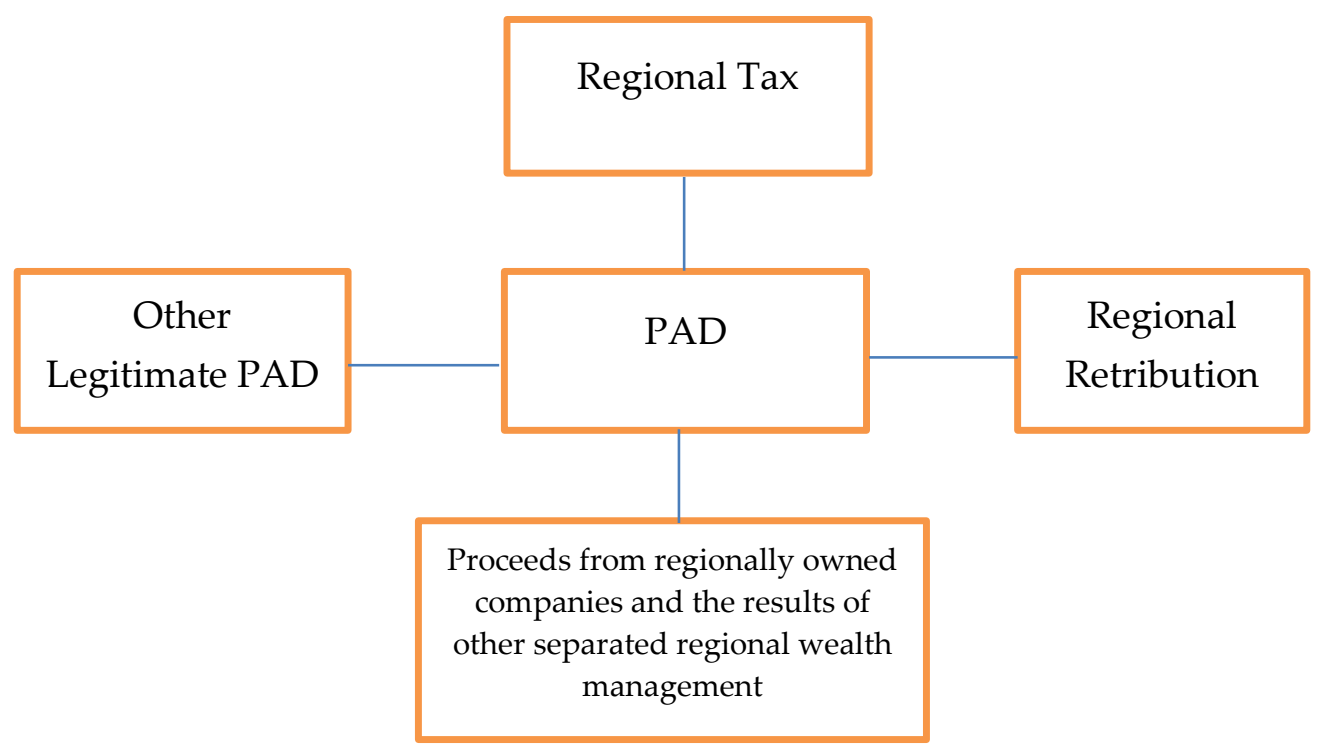

Figure 2. Model Law No. 21 of 2001

This model shows differences in the elements of PAD in Law No. 33 of 2004 concerning Financial Balance between the Central Government and Regional Governments with Law No. 21 of 2001 concerning Special Autonomy for Papua Province, especially in terms of the existence of regional-owned companies. This means that regions in Papua Province can form Regional Owned Enterprises (BUMD) at the provincial and district/city levels.

Various regulations and Government actions towards increasing PAD currently need to be carried out systematically while still encouraging creating a good investment climate. The investment climate plays an important role in increasing PAD. The healthy investment climate can be seen from various factors such as political stability, availability and quality of human resources, quality of infrastructure and supporting facilities, and local governments' role and function that are responsive to the private sector. Besides, the current Maybrat Regency Government still needs to improve in various sectors to meet a good business climate to increase PAD.

For example, in the context of political stability, the Regional Government of Maybrat Regency has experienced prolonged conflict dynamics that directly affect economic conditions, especially in the case of Capital City, which has occurred for eight years. One of them was when there was a debate about the district capital location, namely between the Ayamaru district and the Kumurkek district. The struggle for the Capital City location takes place from the community level to the Constitutional Court. In 2009, the Constitutional Court rejected the lawsuit against judicial review of Law No. 13 of 2009 concerning the Establishment of Maybrat Regency because the applicant is deemed not to have a legal position regarding the material being tested so that the capital is still in Kumurkek. However, five years later, the Constitutional Court chaired by Akil Mochtar again accepted the law's request for judicial review. The Constitutional Court then granted the request 
through Decision Number 66 / PUU-XI / 2013 dated September 19, 2013, and decided that the capital city of Maybrat was in Ayamaru (Antara.com.2018). This decision was strengthened by the Constitutional Court letter Number 808/2000 / HK.004 / 2018 dated April 12, 2018 (release.id, 2018).

However, the Minister of Home Affairs ignored this decision and continued to stick to Law No. 13 of 2009 in which the capital city of Maybrat Regency remains in Kumurkek, Aifat District. Then, on July 21, 2018, to be precise, was remembered as the typical day of peace for the Maybrat conflict, which was attended by the Governor of West Papua Domiggus Mandarin, the Regent, Deputy Regent, and the Regional Secretary of Maybrat Regency (Teras.id, 2018). As a result, the government through the Directorate General of Regional Autonomy of the Ministry of Home Affairs submitted Government Regulation (PP) Number 41 of 2019 concerning the transfer of the capital to Regent Maybrat, which stated that the capital moved from Ayamaru District to Kumurkek, Aifat District (Dirjen Otda, 2019).

The conflict over the capital city location directly resulted in delays in the development process in Maybrat Regency. Maybe at Regency Government personnel as a New Autonomous Region (DOB) are more absorbed in resolving conflicts over the capital city, rather than developing the region itself. The conflict also impacts small investment due to the region's failure to build a healthy investment climate. The conflict also impacted the economic stability that occurred in Maybrat Regency, which was seen from the district's economic dependence on personnel spending. These conditions indicate that the need to accelerate development in Maybrat Regency needs to be done.

The Central Government, together with West Papua Province, needs to pay special attention and serious assistance to the New Autonomous Region (DOB), especially in political conflicts and governance during the transition period. This is especially true in providing guidance and supervision to the Regional Government, carried out by the Central Government in line with the mandate of Government Regulation No. 12 of 2017 concerning Guidance and Supervision of Regional Government Administration. The development of regional autonomy is formed as an effort by the Central Government to facilitate autonomy. At the same time, supervision is carried out to maintain consistency and effectiveness in autonomy administration. Optimizing the Central Government's guidance and supervision function provides a corridor for new autonomous regions to accelerate development in line with regional needs and potential. The role and function of the Central Government in this regard shows that there is a need for active and reactive action against local governments.

In addition to the Central Government's role and function in creating and assisting regions in optimizing resources, the increase in PAD also needs to be supported by the Regional Government's ability to articulate their needs. One thing that can boost PAD is community empowerment, which the Maybrat Regency Government has not done optimally. This can also be seen from community empowerment's function in managing regional potential, which is still considered 
quite minimal. The Maybrat Regency Government felt the need to empower through education and training for the community. This policy is expected to increase and trigger micro, small and medium enterprises (MSMEs), especially in the development of leading sectors. Community empowerment also does not stop at community-based business development and improves the quality of human resources through the provision of tiered, vocational, and vocational education. It is hoped that this will provide skilled labor (skilled labor) and semi-skilled labor to support the investment climate.

However, the community's empowerment needs to be supported by the quality and capability of aperture resources in supporting government wheels. The quality of apparatus resources is felt necessary to create a fluid, active, and adaptive government to change to be ready for dynamic social and economic conditions. The condition of the quality of human resources for the Maybrat Regency apparatus is currently considered less than optimal, in which group II mostly fills the formation of the Government apparatus. It is felt that the Maybrat Regency Government needs to increase the capacity of apparatus resources through formal, non-formal education, training, workshops, and expertise education, which can be carried out through the provision of Government scholarships. These various steps are adjusted and budgeted in the form of policies and borne by the APBD.

The government can also carry out various collaborations with universities to provide education and training to regional apparatus and carry out collaborative research and regional development related to increasing PAD. It is also hoped that the presence of the role of higher education institutions in implementing local government will also provide an understanding of the latest science and technology and can be applied directly to the community. The Maybrat Regency Government has currently collaborated with Cendrawasih University universities to increase community empowerment and determine superior potential. This collaboration is expected to provide understanding and implementation of best practices following the college's studies and research.

Apart from community empowerment, cooperation, and strengthening of apparatus resources. The Maybrat Regency Government also needs to build infrastructure to support economic activities. Regional governments are expected to build community needs by providing markets in the regional, parent, and traditional markets. It is hoped that the establishment of the market will provide accommodation for the community to sell their products, especially forest products, agriculture, livestock, and plantations. The existence of buying and selling space directly impacts the community's economy, which not only has an impact on improving the standard of living but also increases the people's economic enthusiasm for entrepreneurship. This condition will have an impact on the enthusiasm of the UMKM industry in Maybrat Regency.

In the context of the distribution of goods, the Maybrat Regency Government has also integrated the system between the market and public transportation to distribute community products. The existence of a terminal in the market itself 
provides multiple benefits for PAD Maybrat Regency. The government will get taxes and levies from community economic activities and transportation activities such as terminals and city transportation. The existence of transportation also makes it possible to create market expansion for people's products. Besides, the terminal also has a function for regional transportation and those outside the region and borders of Maybrat Regency to create a climate of cooperation between regions.

The Maybrat Regency government building the economic epicenter can also establish regional transportation modes, especially as a connection between districts and distribution of goods and services. This means that the establishment of BUMD as the economic epicenter manager is expected to be able to create accumulated values and benefits from the potential resources of Maybrat Regency in the form of community economic activities. This has also begun to be supported by constructing a national road that connects Maybrat Regency directly to areas such as South Sorong. The epicenter in the form of the Central Business District (CBD) will be a place for each region's production to be exchanged. Forest products are the superior potential of Maybrat Regency, and marine products become the superior potential of South Sorong.

The formation of BUMD is an alternative that can be carried out by the Regional Government in increasing PAD. BUMD itself can be established in managing various potential resource sectors owned by Maybrat Regency. One can be done in the agricultural and plantation sectors, energy and mineral resources (ESDM), transportation, and forestry. Even though in its implementation, the forestry sector and ESDM still collide with the Provincial Government's authority, so it still requires clear regulation, especially the role of the Maybrat Regency Regional Government apart from through profit-sharing funds. The formation of BUMD is one of the ways that are felt to be quite effective in increasing PAD, in which the regions have full management and management of the sector's economic activities.

However, the formation of BUMD itself in Maybrat Regency is currently not the focus of increasing PAD. The Maybrat Regency Government is currently more focused on increasing PAD through tax and retribution revenue. This can be seen from the Maybrat Regency Mid-Term Development Plan (RPJMD), which focuses on local taxes and levies. In 2022, it is expected to create 12 taxes and 24 local levies and be supported by five supporting regulations for the business climate. However, this regulation is still in the planning stage until now, so it cannot be widely implemented.

The need for the Central Government in a new autonomous regional government, such as the Maybrat Regency, is essential, especially to resolve conflicts. Learning from the condition of Maybrat Regency, which spent its first eight years of energy and time struggling with the conflict over the choice of the capital city, so the time to build them has only recently started. The presence of the Central Government is expected to be able to provide preventive action against this condition. This means that assistance for new autonomous regions should be done, 
especially for areas in Papua and West Papua Provinces that have "specialties" compared to other regions.

The role of assistants and mentors in local government activities can also be carried out by the governor, who functions as an extension of the region. This assistance can be carried out through guidance and supervision to safeguard the corridors of development and good governance activities. This condition makes the Regional Government have a direct two-way response between the regions and the center. This means that the central government plays a role not only as a facilitator but also as a collaborator in regional government activities.

This condition shows that regional expansion means regulating their region and must ensure a conducive situation for the region itself. There is a risk of misperception of autonomy itself, which often leads to conflicts that hinder regional growth. The presence of the Central Government also provides certainty for new autonomous regions to continue running according to the existing regulatory corridors. This means that the Central Government is required to be active in their role and function as the supra-structure of government and ensure that their delegation of power runs properly.

Regional Governments, especially as the main actors in the implementation of regional autonomy, have roles and functions in carrying out their government's wheels. This condition is based on Law No. 23 of 2014 concerning the Regional Government. The conditions are quite different in Papua and West Papua Provinces, which have additional regulations on government activities regulated in Law no. 21 of 2001 concerning Special Autonomy for Papua Province. In the process, the government needs various additional funds needed to develop regions that are delegated in the form of authority. One of them can be done through an increase in PAD, which is regulated in both laws. The authority is divided into 32 main functions, which are divided into three parts, namely basic services, non-basic services, and assistance tasks. The Regional Government must exercise these various powers for the welfare of their people.

\section{CONCLUSION}

The results showed that the condition of Maybrat Regency as a New Autonomous Region (DOB) requires special attention, especially assistance with the Central Government. The central government's special attention is through fostering and supervising political conflicts and governance during the transition period, based on the mandate of Government Regulation no. 12 of 2017 concerning Guidance and Supervision of Regional Government Administration. Guidance is an effort made by the Central Government to facilitate the process of implementing autonomy. At the same time, supervision maintains consistency and effectiveness in the administration of independence following the nation's corridors and goals. 
Then, coaching also impacts better handling of political stabilization and the responsibility of the Central Government to participate in overseeing the acceleration of the development of active and reactive actions towards Regional Governments that are in line with regional needs and potentials.

Meanwhile, concerning PAD's optimization, the conflict impacts hampered investment in providing political stability concerning a healthy investment climate. Besides, conflict is an obstacle to economic stagnation, which can be seen from the district's economic dependence on personnel spending. This condition shows that the urgency of accelerating development in the Maybrat Regency needs to be carried out and given careful attention.

\section{REFERENCES}

1. Boetti, L., Piacenza, M., \& Turati, G. (2012). Decentralization and Local Governments' Performance: How Does Fiscal Autonomy Affect Spending Efficiency?. FinanzArchiv/Public Finance Analysis, 269-302.

2. Clark, G. L. (1984). A theory of Local Autonomy. Annals of the Association of American Geographers, 74(2), 195-208.

3. Denzin, N. K. (2010). Moments, Mixed Methods, and Paradigm Dialogs. Qualitative inquiry, 16(6), 419-427.

4. Guba, E. G. (1990). The Paradigm Dialog. In Alternative Paradigms Conference, Mar 1989, Indiana U, School of Education, San Francisco, CA, US. Sage Publications, Inc.

5. Hadiz, V. R. (2004). Decentralization And Democracy In Indonesia: A Critique Of Neo-Institutionalist Perspectives. Development and Change, 35(4), 697-718.

6. Haris, S. (2005). Desentralisasi dan Otonomi Daerah: Desentralisasi, Demokratisasi $\mathcal{E}$ Akuntabilitas Pemerintahan Daerah. Yayasan Obor Indonesia.

7. Isufaj, M. (2014). Decentralization and Increased Autonomy in Local Governments. Procedia-Social and Behavioral Sciences, 109, 459-463.

8. Joku, F. (2007). Problem and Prospectus of the Special Autonomy Law. The University of Sidney.

9. King, P. (2004). West Papua E Indonesia Since Suharto: Independence, Autonomy, Or Chaos?. UNSW Press.

10. Kuhn, T. S. (1970). The Structure of Scientific Revolutions, 2 nd enl. ed. University of Chicago Press.

11. Law number 21 of 2001 regarding Special Autonomy for Papua and West Papua Provinces

12. Law number 33 of 2004 concerning Regional Financial Balance

13. McGibbon, R. (2003). Between Rights and Repression: The Politics of Special Autonomy in Papua. Local Power and Politics in Indonesia: Decentralisation $\mathcal{E}$ Democratisation, 194-213.

14. Mualim, M. (2010). Pengaruh Desentralisasi Fiskal terhadap Pertumbuhan Ekonomi dan Peran Kelembagaan Dana Otonomi Khusus Papua di Provinsi Papua Barat (Doctoral dissertation, Universitas Brawijaya). 
15. Muin, F. (2014). Otonomi Daerah dalam Perspektif Pembagian Urusan Pemerintah-Pemerintah Daerah dan Keuangan Daerah. Fiat Justisia, 8(1), 69-79.

16. Musa'ad, M. A. (2016). Kontekstualisasi Pelaksanaan Otonomi Khusus di Provinsi Papua: Perspektif Struktur dan Kewenangan Pemerintahan. Kajian, 16(2), 357-385.

17. Nordholt, H. S. (2005). Decentralization in Indonesia: Less State, More Democracy?. In Politicising Democracy (pp. 29-50). Palgrave Macmillan, London.

18. Nuarisa, S. A. (2013). Pengaruh PAD, DAU dan DAK Terhadap Pengalokasian Anggaran Belanja Modal. Accounting Analysis Journal, 2(1).

19. Simanjuntak, K. M. (2015). Implementasi Kebijakan Desentralisasi Pemerintahan di Indonesia. Jurnal Bina Praja: Journal of Home Affairs Governance, 7(2), 111-130.

20. Thomas, D. R. (2003). A General Inductive Approach for Qualitative Data Analysis. New Zealand: University of Auckland

21. Tryatmoko, M. W. (2016). Politik Kebijakan Pengelolaan Dana Otonomi Khusus Papua. Jurnal Penelitian Politik, 9(1), 18.

22. Wandira, A. G. (2013). Pengaruh PAD, DAU, DAK, dan DBH terhadap pengalokasian belanja modal. Accounting Analysis Journal, 2(1).

23. Webb-Gannon, C. (2014). Merdeka in West Papua: Peace, Justice, and Political Independence. Anthropologica, 353-367. 